\title{
Investigation of Arsenic-Resistant, Arsenite-Oxidizing Bacteria for Plant Growth Promoting Traits Isolated From Arsenic Contaminated Soils
}

Aritri Laha ( $\sim$ lahaaritri@gmail.com )

Bidhan Chandra Krishi Viswa Vidyalaya https://orcid.org/0000-0002-8434-3670

Somnath Bhattacharyya

Bidhan Chandra Krishi Viswa Vidyalaya

Sudip Sengupta

Bidhan Chandra Krishi Viswa Vidyalaya

Kallol Bhattacharyya

Bidhan Chandra Krishi Viswa Vidyalaya

Sanjoy GuhaRoy

West Bengal State University

\section{Original Paper}

Keywords: Arsenic (As), plant-growth promotion, Burkholderia, As-oxidase activity, minimum inhibitory concentration

Posted Date: February 17th, 2021

DOI: https://doi.org/10.21203/rs.3.rs-196992/v1

License: (1) This work is licensed under a Creative Commons Attribution 4.0 International License. Read Full License 


\section{Abstract}

The menace of arsenic (As) pollution being severe warrants opting for low cost microbial remediation strategies. The present study of identifying suitable bacterial strains led to isolation of eleven As-tolerant strains from the As contaminated rhizosphere soils of West Bengal, India. They were found to oxidize/reduce $55 \%-31.6 \%$ of $5 \mathrm{mM} \mathrm{As}(\mathrm{III})$ and $73 \%-37.6 \%$ of $5 \mathrm{mM} \mathrm{As}(\mathrm{V})$ within $12 \mathrm{hrs}$. The four isolates (BcAl-1, JN 73, LAR-2 and AR-30) had high level of As(III) oxidase activity along with higher level of As(V) and As(III) resistance. The presence of $a o x B$ gene was observed in these four $A s$ (III) oxidizing isolates. Evaluation of plant growth promoting characteristics revealed that BcAl-1 (Burkholderia cepacia), JN73 (Burkholderia metallica), AR-30 (Burkholderia cenocepacia) and LAR-2 (Burkholderia sp) had enormous plant growth-promoting characteristics (PGP), including ability to solubilize phosphate, siderophore production, indole acetic acid like molecules production, ACC deaminase production and nodule formation under As stressed condition. BcAl-1 and JN73 emerged as the most promising traits in As removal as well as plant growth promotion.

\section{Introduction}

The eastern India (West Bengal mainly) and Bangladesh are severe sufferers of As (As) contamination owing to exposure of living system via water and food (Chowdhury et al., 2001; Bhattacharya et al., 2010; Chakraborti et al., 2015). The use of As or heavy metal enriched water in agricultural fields is the reason of its significant build-up in soil (Abedin et al., 2002; Meharg and Rahman, 2003) and subsequent accumulation in standing crop (Matera et al., 2003; Bogdan and Schenk, 2009). Generally As residues are found in the top layer of soil because of its low volatility and low solubility, and further indulge in As entry in crops (Das et al., 2013). The As has both organic and inorganic forms (Matschullat, 2000) and in environment found as an oxyanion (Frankenberger Jr. and Arshad, 2002). The insurmountable health risk fatalities in As polluted soil and water sites (Gonza'lez and Gonza'lez-Cha'vez, 2006; Xiong et al., 2019) accompanied by the high cost of adopting remediation measures puts forward the bioremediation tool by utilizing novel As-tolerant microbes (Ghosh et al., 2011) or microbiological methods (Kumpiene et al., 2006).

The As built-up in soil is supposed to reduce gradually through plant accumulation and by other environmental process such as leaching (Hartley et al., 2004), erosion, methylation (Srivastava et al., 2013). In As polluted area, the soil microbes (Farooq et al., 2016) tend to adapt strategies to survive in contaminated atmosphere; and often are able to utilize the toxic As as nutrient for their metabolisms and proliferation (Das et al., 2013). These microorganisms may help in metal decontamination (Bhattacharyya and Sengupta, 2020) and promote plant growth simultaneously (Li and Ramakrishna, 2011; Srivastava et al., 2013).

Some specific enzymes or respiratory chains (responsible for redox transformation of As) are present in bacteria. These microbes can use As as an electron donor or electron acceptor and may also help in As detoxification mechanisms. These may be related with As resistance gene or ars operon system, As respiratory reduction gene or arr and As(III) oxidation genes or aox/aro/aso system. In case of energy metabolisms As(III) serves as an electron donor, gene encoding proteins are encoded as aro (Santini and van den Hoven, 2004). Some genes which have no responsibility in energy metabolisms but play a vital role in As detoxification are found in heterotrophic As(III) oxidizing bacteria. These genes are called aox (Muller et al., 2003) and aso (Kashyap et al., 2006). Phylogenetically As(III) oxidizing bacteria are diverse. As(III) oxidase enzyme is a protein which belongs to dimethyl sulphoxide reductase family of the molobodepterin containing protein (aro A/aso A/aox B) and Fe-X Reiske protein (Ellis et al., 2001; Muller et al., 2003; Santini and van den Hoven, 2004). Many of the betaproteobacteria such as Burkholderia sp, Bosea sp, Alkaligens sp. were found to carry the aox B subunit of As(III) oxidase gene.

Further, some rhizospheric microbes also play the role through unique As resistance and PGP characters. These adopted indigenous soil microbes may manifest a bunch of PGP traits through secretion of 1-aminocyclopropane-1-carboxylate (ACC), deaminase, indole-3-acetic acid (IAA), phosphate solubilizers, producing siderophores that reduce metal toxicity and encourage plant-assisted bioremediation and enhances nitrogenase activity also (Ma et al., 2011; Rajkumar et al., 2012; de-Bashan et al., 2012). Most remarkably, such PGP characters remain active under intense As stress (Ghosh et al., 2018).

In this backdrop, we have planned to select and identify efficient As-resistant bacteria from contaminated soil, precisely from the rhizospheric zone, to investigate the plant growth promoting attributes of identified bacteria with a view to harvest their capacity to develop plant's resistance to stress conditions, encourage plant growth, and give a path to contribute an accelerated remediation of As polluted soils (Ma et al., 2011; Rajkumar et al., 2012; de-Bashan et al., 2012; El-Meihy et al., 2019).

Thus, the objectives of the present investigations are, precisely, to isolate As tolerant bacterial strains from the contaminated agricultural soil of West Bengal and explore their PGP potentialities through plant-microbe connections in an As stressed environment.

\section{Materials And Methods}




\subsection{Analysis of soil samples:}

Soil samples ( $2 \mathrm{~cm}$ diameter, $10 \mathrm{~cm}$ depth) were collected aseptically from contaminated zone of Chakdaha, West Bengal (230 $5^{\prime} \mathrm{N}$ latitude and $88^{\circ} 54^{\prime} \mathrm{E}$ longitude), India where As concentrations in the ground water is above World Health Organization (WHO)-defined safe limit (Sarkar et al., 2012). Atomic Absorption Spectrophotometer (AAS) coupled with hydride generator was used to assess the soil load of total (Sparks et al., 2006) and available As (Johnston and Barnard, 1979). Total bacterial population and those imparting resistance to As of the soil were also measured (Bachate et al., 2009).

\subsection{Enrichment of As tolerant bacteria:}

$2 \mathrm{~g}$ of soil (taken from groundnut and lentil rhizosphere separately) was suspended in $2 \mathrm{~mL}$ sterile distilled water, $1 \mathrm{~mL}$ of each was resuspended in Yeast Extract Mannitol (YEM) liquid medium separately in two conical flasks, spiked with $1 \mathrm{mM}$ As(III) and $1 \mathrm{mM}$ As(V) and allowed to incubate for 2 days at $30^{\circ} \mathrm{C}$ (Kinegam et al., 2008). Subsequently, an enrichment culture was prepared by transferring $2 \mathrm{~mL}$ of cultures in YEM. Procedure was repeated twice. Around $0.1 \mathrm{~mL}$ of As spiked enriched culture was spread on a medium containing YEMA (Yeast Extract Mannitol Agar). Some distinct colonies of As tolerant bacteria were picked for isolation after $24 \mathrm{hrs}$ incubation.

\subsection{As oxidation and reduction activity by the strains:}

Silver nitrate $\left(\mathrm{AgNO}_{3}\right)$ method under the standard condition (Majumder et al., 2013a) was used to screen As-oxidizing bacterial isolates. The isolates, cultured on solidified chemically defined medium with $1 \mathrm{mM} \mathrm{As}(\mathrm{III})$ supplementation were kept for $48 \mathrm{~h}$ at $30^{\circ} \mathrm{C} .0 .1 \mathrm{M} \mathrm{AgNO}_{3}$ solutions were flooded over the plates and the colony colour change was recorded. $\mathrm{AgNO}_{3}$ upon reaction with As(III), produces a bright yellow silver ortho $\mathrm{As}(\mathrm{III})\left(\mathrm{Ag}_{3} \mathrm{AsO}_{3}\right)$ precipitate, whereas ortho $\mathrm{As}(\mathrm{V})\left(\mathrm{Ag}_{3} \mathrm{AsO}_{4}\right)$ precipitate, produced by the reaction of $\mathrm{AgNO} \mathrm{O}_{3}$ with $\mathrm{As}(\mathrm{V})$ is brownish silver in nature. The As-oxidizing ability of the bacterial strains was further validated through micro plate technique (Simeonova et al., 2004). Triplicating the assays, the brown colour precipitate forming strains were isolated as As-oxidising bacteria.

\subsection{As accumulation and oxidation/reduction:}

Freshly prepared culture (approximately $100 \mu \mathrm{L}$ ) of As resistant bacterial strains was inoculated in $50 \mathrm{~mL}$ YEM liquid culture medium previously spiked with $5 \mathrm{mM}$ of $\mathrm{As}(\mathrm{V})$ and $\mathrm{As}(\mathrm{III})$ in $100 \mathrm{ml}$ conical flask, with proper mercuric nitrate impregnated filter paper capping (Majumder et al., 2013b). The set-up was incubated at room temperature for $12 \mathrm{hrs}$ in a shaker. First the filter papers were removed, followed by separation of cell pellet and liquid culture media by centrifugation at $10000 \mathrm{rpm}$ for 2 minutes. As concentration were measured with an Atomic Absorption Spectrophotometer by standard method (Majumder et al., 2013b). Each experiment was repeated thrice.

\subsection{MIC (Minimum inhibitory concentration) study of the bacteria:}

The MIC value is the lowest concentration of $\mathrm{As}(\mathrm{V})$ or As(III) which entirely hampers microbial activity (Majumder et al., 2013a, b). The MIC test has been adopted to isolate $\mathrm{As}(\mathrm{III})$ (III) and $\mathrm{As}(\mathrm{V})$ resistant bacterial strains. $1.0 \mathrm{~mL}$ aliquot was collected from overnight growing bacterial cultures, were allowed to incubate in two conical flasks containing $99.0 \mathrm{~mL}$ of YEM liquid medium, spiked with either As(III) $\left(\mathrm{NaAsO}_{2} ; 1-50 \mathrm{mM}\right)$ or $\mathrm{As}(\mathrm{V})\left(\mathrm{Na}_{2} \mathrm{HAsO}_{4} \cdot 7 \mathrm{H}_{2} \mathrm{O} ; 1-500 \mathrm{mM}\right.$ ) separately and incubated at $30^{\circ} \mathrm{C}$ with $48 \mathrm{hrs}$ of shaking. The OD (optical density, measurement of microbial growth) of the bacterial cultures was detected using a microprocessor based UV-Vis spectrophotometer at $\lambda_{\max } \cong 600 \mathrm{~nm}$

\subsection{As(III) oxidase assay:}

The As tolerant bacterial isolates were grown in chemically defined medium (CDM) spiked with $30 \mathrm{mM}$ of As(III). After centrifugation at $10,000$ rpm for 2 minutes late log-phase cells were collected. Then cells were washed by using $50 \mathrm{mM} \mathrm{Tris-HCl} \mathrm{buffer} \mathrm{(pH} 8.0)$ and suspended in $2 \mathrm{~mL}$ buffer having $0.5 \mathrm{mM}$ phenyl methyl sulfonyl fluoride (PMSF) and lysozyme. Cell suspensions were chrono-sequentially incubated for $2 \mathrm{~h}$ and sonicated for disrupting the cellular membrane. Then after centrifugation at 10,000 rpm for 30 min cell debris was removed (Bachate et al. 2012). Finally the protein concentrations were measured by using bovine serum albumin (Sigma) as a standard. The As(III) oxidase assay was performed using a method previously described by Anderson et al. (1992).

\subsection{Identification of the As tolerant bacteria:}

The selected As oxidizing bacterial genomic DNA was extracted and PCR amplification for molecular identification by $16 \mathrm{~S}$ rRNA sequence analysis. Total genomic DNA of selected bacteria was extracted (Majumder et al., 2013a) and PCR amplification of 16S rRNA gene with forward primer 27F 5'-AGA GTT TGA TCM TGG CTC AG-3' and the reverse primer 1492R 5'-GGY TAC CTT GTTACG ACT-3' (Chromous Biotech Private Limited, India) were performed. 
The bacterial strains were studied for Gram reaction, colony morphology and characterized for catalase, urease, and oxidase activities by standard protocols (Holtz, 1993).

\subsection{Scanning Electron Microscopic (SEM) Study}

The SEM study of arsenic resistant bacteria was performed following Dey et al. (2016). For the SEM study the harvested bacterial cells were at first washed with sodium phosphate buffer $(\mathrm{pH}$ 7.4) followed by preparation of a bacterial smear on a cover glass and heat fixing over a flame for 1-2 sec followed by fixation with $2.5 \%$ glutaraldehyde (aqueous) for $45 \mathrm{~min}$. The slides were then dehydrated passing through $50-90 \%$ of alcohol solutions and finally through absolute alcohol for $5 \mathrm{~min}$ each. After that the samples on the cover glass were gold coated and observed under a $15 \mathrm{kV}$ scanning electron microscope (HITACHI, S-530, SEM and ELKO Engineering).

\subsection{Detection of aoxB gene}

The selected As oxidizing bacterial genomic DNA were extracted and PCR amplification of aoxB gene (As(III) oxidase gene) was carried out by using the forward primer 69F 5'-TGY ATYGTNGGNTGYGGNTAYMA-3' and reverse primer 1374R 5'-TANCCYTCYTGRTGNCCNCC-3' (Rhine et al., 2007). The reaction mixture contains 1 X PCR buffer, $0.2 \mathrm{mM}$ dNTPs, $1.5 \mathrm{mM} \mathrm{MgCl} 2,1 \mathrm{M}$ of each primer, $25 \mathrm{ng}$ of DNA Template and 2 units of Taq DNA Polymerase. To maintain the final reaction volume of $25 \mu \mathrm{L}$, the remaining volume was filled by deionized water. All the PCR Products were gel eluted by using Wizard SV gel and PCR clean up system (Promega, Madison, WI). The sequencing of aoxB gene (BcAl-1, JN 73, AR-30, and LAR-2) was done with 69 F Primers (Chromous Biotech Private Limited). The aoxB gene sequences were compared by using nucleotide BLAST algorithm with a public data base.

\subsection{Phylogenetic tree:}

Phylogenetic tree of 16S rRNA gene and As(III) oxidase gene sequences of the As oxidizing bacteria were drawn through Maximum likelihood algorithms and bootstrapping procedure to statistically test branch support via Phylogeny.fr web service (Dereeper et al., 2008). 500 bootstraps were taken to construct the phylogenetic tree.

\subsection{Plant growth promoting (PGP) attributes of As tolerant bacteria:}

The PGP properties (IAA-production, ACC Deaminase activity, phosphate solubilization, nodulation and siderophore production) of the bacteria were assessed in vitro in culture medium spiked both by $\mathrm{As}(\mathrm{V})$ and $\mathrm{As}(\mathrm{III})$ (spiking levels being $0 \mathrm{mg} / \mathrm{L}, 15 \mathrm{mg} / \mathrm{L}$, and $30 \mathrm{mg} / \mathrm{L}$ $\operatorname{As}(I I I) / \operatorname{As}(\mathrm{V}))$.

\subsubsection{ACC Deaminase activity}

The activity of ACC Deaminase enzyme is attributed to the quantity of a-ketobutyric acid production by breakdown of ACC (Penrose and Glick, 2003) by the strains. For assessment, a minimal medium was prepared using 1-aminocyclopropane-1-carboxylic acid or ACC $\left(3 \mathrm{gL}^{-1}\right)$ as a source of nitrogen, spiked with three different concentrations of $A s(V)$ and $A s(I I I)(0,15,30 \mathrm{mg} / \mathrm{L})$ separately and the bacterial cells were grown. The quantity of ketobutyrate (KB) formed per mg of protein per hour is the total value of the specific enzyme activity (Penrose and Glick, 2003).

\subsubsection{Screening of Indole Acetic Acid (IAA)}

The IAA production potential of the selected As resistant isolates were determined by growing them in a L-tryptophan $(0.5 \mathrm{mg} / \mathrm{ml})$ supplemented minimal medium in presence of different concentration of $A s(0,15,30 \mathrm{mg} / \mathrm{L})$ and incubated in dark for 5 days at $30^{\circ} \mathrm{C}$. The experiment constitutes transferring $2 \mathrm{ml}$ bacterial suspension in $100 \mu \mathrm{l} 10 \mathrm{mM}$ ortho phosphoric acid and $4 \mathrm{ml}$ Salkowski's reagent $(2 \%$ solution of $0.5 \mathrm{M} \mathrm{FeCl}_{3}$ in $35 \%$ perchloric acid) in a test tube. The entire mixture was vigorously shaken prior to incubation for 45 min until a pink colour develops. Absorbance of the resultant solution was measured at $530 \mathrm{~nm}$ for obtaining the content of IAA like molecules in liquid culture medium (Das et al., 2014).

\subsubsection{Ability to solubilize phosphate}

This encompasses growing the bacterial strains in Pikovskaya's medium (Sundararao, 1963) (containing $0.5 \%$ of tri calcium phosphate (TCP) spiked with three levels of $\mathrm{As}(\mathrm{V})$ and $\mathrm{As}$ (III) $0,15,30 \mathrm{mg} / \mathrm{kg}$ ) at $30^{\circ} \mathrm{C}$ for $5-6$ days and $170 \mathrm{rev} / \mathrm{min}$; followed by centrifugation at 6500 times gravity and supernatant collection. The phosphate solubilization in supernatant of culture medium was estimated by standard method (Zaidi et al., 2006).

\subsubsection{Nodulation efficiency}


The nodulation efficiency of bacterial strains (Reed and Glick, 2013) was assessed through a pot study. Soils were sterilized and the seeds of groundnut were sown in the sterilized soil spiked with $A s(0,15,30 \mathrm{mg} / \mathrm{kg})$ and the nodule counts were taken after 30 days.

\subsubsection{Screening for siderophore production:}

The ability of the As tolerant bacterial isolates to produce siderophores was qualitatively assayed by using Chrome Azural S method of Schwyn and Neilands following Das et al. (2014). The bacterial strains were grown in MM9 (Tris buffer, casamino acids (0.3\%), L-glutamic acid $(0.05 \%),(+)$ - biotin $(0.5 \mathrm{ppm})$, and sucrose $(0.2 \%)$ ) liquid medium with the absence of Fe and allowed to incubate for 5 days at $30^{\circ} \mathrm{C}$ temperature at $175 \mathrm{rev} / \mathrm{min}$. For control $0.2 \mu \mathrm{M}$ of iron (freshly prepared, filter sterilized $\mathrm{FeSO}_{4} .7 \mathrm{H}_{2} \mathrm{O}$ stock solution) was also inoculated. The stationary phase bacterial culture were collected and pelleted by centrifugation (6,500 $\mathrm{xg}$ for 15 minutes). In supernatant solution, the most important qualitative conformation of the presence of siderophore is simply the color change from blue to orange.

\subsection{Statistical analysis}

Statistical computations like Duncan's multiple range post hoc test, simple descriptive statistics, etc. were performed using Microsoft Excel 2016 and SPSS version 23.0.

\section{Results}

\subsection{Characterization of experimental site}

The assessment of the level of As contamination of the selected soil under study were chemically attributed in terms of total (tri-acid extracted) and Olsen-extractable available As. Results revealed a considerable load of the heavy metal of $17.2 \pm 1.72$ and $1.50 \pm 0.27 \mathrm{mg}$ $\mathrm{kg}^{-1}$ respectively. The total microbial count from the soil was $6.4 \pm 0.07 \mathrm{log} \mathrm{CFU} / \mathrm{g}$. The As resistant microbial count was $3.6 \pm 0.09 \mathrm{log}$ $\mathrm{CFU} / \mathrm{g}$ soil (presented as mean of three observations $\pm S D$ ). The considerably high proportion of As resistant microbial count can be a cue to address the problem of As contamination more efficiently through a low cost microbial remediation technique.

\subsection{Assessment of As resistant bacteria from enrichment culture:}

Employing the enrichment culture techniques for possible isolation of As resistant bacterial isolates in Yeast Extract Mannitol (YEMA) solid medium spiked with different $\mathrm{As}(\mathrm{V})$ and $\mathrm{As}(\mathrm{III})$ concentration, few colonies were observed. Eleven distinct colonies, namely, BcAL-1, JN 73, LAR-2, AR-30, GAR-1, GAR-2, LAR-7, GAR-11, LAR-20, LAR-3 and SAR-05, were picked from the plates and allowed for further growth and study.

\subsection{Arsenic accumulation and oxidation-reduction potential of bacterial isolates:}

The isolated eleven bacterial strains were investigated for their potential of As accumulation and oxidation/reduction. Initially, a qualitative analysis of ability of the bacterial strains to form $\mathrm{Ag}_{3} \mathrm{AsO}_{3}$ or $\mathrm{Ag}_{3} \mathrm{AsO}_{4}$ from the $\mathrm{AgNO}_{3}$ solution as visualized by the intensity of colour change to bright yellow and brownish silver was categorized. Four isolates were observed to have distinguishably brighter colour change. To confirm the test, the As accumulation and oxidation/reduction potential of the isolates were addressed through an quantitative estimation by incubating for $12 \mathrm{hr}$ in a liquid culture medium spiked with $5 \mathrm{mM} \mathrm{As}(\mathrm{V})$ and $\mathrm{As}(\mathrm{III})$. The As content in cell pellet, liquid medium and impregnated filter paper were separately analyzed with the purpose of attaining the quantity of As oxidized or reduced (filter paper) and accumulated (in cell pellet). The results interestingly revealed the similar pattern of microbial alteration of As as in the qualitative test. The strains BcAL-1, JN 73, LAR-2 and AR-30 had shown significant ability to oxidize/reduce and accumulate As and thus enunciated the reduction of highest quantity of As from the initial concentration. As evident from the Table-1, the As recovery from the filter paper (a measure of As oxidization-reduction potential) followed the trend of BcAL-1 $(1.63 \pm 0.43)>J N 73(1.60 \pm 0.69)>$ LAR-2 (1.59 \pm 0.66$)>A R-30$ $(1.56 \pm 0.71)$ for As $(V)$ and BcAL-1 $(1.08 \pm 0.61)>J N 73(1.07 \pm 0.80)>$ LAR-2 $(1.03 \pm 0.50)>A R-30(1.01 \pm 0.63)$ for As (III). The bacterial strains BcAL-1 and JN 73 have shown maximum cellular absorption (40/39\% for As(V) and 36\% for As(III)), oxidation/reduction of As(III) (21/22\%) and $\mathrm{As}(\mathrm{V})(33 / 32 \%)$ while left least residues (25/26\% for As(V) and 40\% for As(III)); (Fig-1) in solution followed by LAR-2 > AR-30.

\subsection{MIC and arsenite oxidase activity of the selected bacterial isolates:}

The four most efficient strains as obtained from the previous section were tested for their minimum inhibitory concentration of As. The results in Table-2 revealed BcAL-1 had highest MIC value (408 mM for As(V) and $46.2 \mathrm{mM}$ for As(III)) followed by JN 73 (390 mM for As(V) and $41.2 \mathrm{mM}$ for As(III)). The MIC values of the remaining two strains were considerably lower, as LAR-2 (300 mM, As(V) and $31.3 \mathrm{mM}$, As(III))>AR-30 (275 mM, As(V) and $28.1 \mathrm{mM}, \mathrm{As}(\mathrm{III}))$. The strain, SAR-05, as evident from both Table-1 and 2, showing no resistance to As, was taken as control. 
The highest MIC value carrying bacteria also had the highest arsenite enzyme activity. As in Table 2, the specific As(III) oxidase activity of these four bacterial isolates (BcAL-1, JN 73, LAR-2 and AR-30) were 5.82, 5.30, 4.97, $4.60 \mathrm{nM} \mathrm{min}^{-1} \mathrm{mg}^{-1}$ of protein respectively. Concurrently, the result brought about the synchrony that the bacterial strains having higher MIC value will have the higher As (III) oxidase activity.

\subsection{Biochemical characterization and identification of the As-resistant PGP Bacteria}

All the selected strains of bacteria were found to be gram negative and rod shaped. The strains (BcAL- 1 , JN 73, LAR-2 and AR-30) screened on the basis of phenotypic and biochemical tests have been represented in Table-3. All these strains were found to be oxidase, catalase and urease positive. Further employing 16S rRNA gene sequencing a phylogenetic tree was prepared (Fig-2). These identified bacterial isolates thus assumed to be Burkholderia cepacia (BcAL-1, accession number KJ461686), Burkholderia metallica (JN 73, accession number KJ507654), Burkholderia sp. (LAR-2, accession number MK634685 and Burkholderia cenocepacia (AR-30, accession number KY992359), as in Table-4. Further to confirm the results, the SEM study of the bacterial isolates (Fig- 3) was categorized.

\subsection{Identification of arsenite oxidase gene:}

The As(III) oxidase gene was detected in our selected As(III) oxidizing bacteria. A fragment of $1200 \mathrm{bp}$ was amplified via polymerase chain reaction (PCR) obtained from the genomic DNA of BcAL-1, JN 73, LAR-2 and AR-30 (Fig-4). Based on the gene sequencing, the sequences were submitted to gene bankit and the accession number was obtained. A phylogenetic tree of As(III) oxidase gene sequences of the As oxidizing bacteria were drawn (Fig-5) through Maximum likelihood algorithms and bootstrapping procedure.

\subsection{Potential plant growth promoting attributes in screened As tolerant bacteria}

The plant growth promoting traits of the four most efficient As tolerant isolates and one control (SAR-05) isolate were categorized. All of these strains were able to solubilize phosphate, produce IAA and ACC Deaminase under As(V) and As (III) stressed condition. BcAL-1, JN 73, LAR-2 and AR-30 were observed to solubilize highest amount of phosphate $(570,563,553,560 \mu \mathrm{g} / \mathrm{L})$ under As free condition and even solubilized significant amount of phosphate when the culture medium are spiked with 15 and $30 \mathrm{mg} / \mathrm{L}$ of $\mathrm{As}(\mathrm{V})$ and $\mathrm{As}(\mathrm{III})$ (Table 5 and 6$)$.

BCAL-1 was the best performer in nodulation, IAA production and ACC production both in As free and As stressed condition. Stresses imposed by $\mathrm{As}(\mathrm{V})$ spiking failed to effect phosphate solubilization, IAA production, ACC Deminase activity and nodulation significantly while under As(III) stress, phosphate solubilization, IAA production, siderophore production and ACC Deminase production were significantly impacted (Table-5 and 6). Comparing all the aspects of PGP in the selected bacterial isolates, two isolates, namely BcAL-1 and JN 73 were able to produce siderophore under all conditions, which the other two strains failed at higher As stress condition.

\section{Discussion}

\subsection{Identification and isolation of As-resistant bacterial strains from contaminated soils:}

In the course of identification and characterization of resistant PGP bacteria from As polluted area in the present investigation BcAL-1 (Burkholderia cepacia) bacterial isolate had emerged with a high MIC towards As(V) (408 mM) and As(III) (46.2 mM) which is higher than previously reported Geobacillus stearothermophilus, Bacillus megaterium, Rhodobacter sphaeroides with MIC values of 380 mM, 400 mM, $400 \mathrm{mM}$ of $\mathrm{As}(\mathrm{V})$ and $40 \mathrm{mM}, 47 \mathrm{mM}, 46.7 \mathrm{mM}$ of As(III) in agricultural soils (Majumder et al., 2013a, 2013b) and also greater than Asoxidizing, As-resistant bacteria in soil (183 mM As(V) and $6 \mathrm{mM}$ of As(III); Srivastava et al., 2013), in ground water (200 mM As(V) and 5 mM As(III); Liao et al., 2011), in mines (10 mM As(V); Botes et al., 2007), and in estuaries (400 mM As(V) and 10 mM As(III); Jackson et al., 2005). Microbes can also bioaccumulate As (Garnaga et al., 2006). Here bacterial isolates BcAL-1 and JN 73 have also shown maximum cellular absorption (40/39\% for $\mathrm{As}(\mathrm{V})$ and $36 \%$ for $\mathrm{As}(\mathrm{III}))$.

\subsection{Arsenite oxidase activity of bacterial strains and their genetic base:}

The bacteria isolated from the contaminated soil having As resistance develop a special type of tolerance mechanisms to survive in metal contaminated environment. They contain ars genetic system which enables the resistant mechanisms to endure in As contaminated soil (Majumder et al., 2013a). Newer studies revealed that such toxicant resistant bacteria contain a number of plant growth promoting (PGP) characters (Ghosh et al., 2018). Our candidate isolates BcAL-1 (Burkholderia cepacia) and JN73 (Burkholderia metallica) had As(III) oxidase enzyme activity 5.82 and $5.30 \mathrm{nM} \mathrm{min}^{-1} \mathrm{mg}^{-1}$ protein respectively. Similar reports with Arthrobacter sp. $\left(10 \mathrm{nM} \mathrm{min}{ }^{-1} \mathrm{mg}^{-1} \mathrm{protein}\right.$ Prasad et al., 2009), $\beta$-proteobacteria (12 nM min ${ }^{-1} \mathrm{mg}^{-1}$ protein; Bachate et al., 2012) had shown high As(III) oxidase enzyme activity. The best performing isolates in the current experiment, BcAL-1 and JN 73 were found to remove more than $70 \%$ As(III) and $57 \%$ of As(V) from liquid culture medium. Such efficiencies are formidably higher than previously reported bacteria like Staphylococcous sp. (volatilizing $24 \%$ As(V) 
and 26\% As(III); Srivastava et al., 2012) and Alcaligenes sp. (oxidizing 1 mM As(III) within 40 hr; Yoon et al., 2009). As(III) oxidase system was also reported in Proteobacteria (Lebrun et al., 2003). Different genera of proteobacteria such as, Burkholderia, Alcaligenes,

Methylobacterium, Bradyrhizobium and Bosea (Quéméneur et al., 2008) carry the As(III) oxidase genetic system. The As oxidizing capacity of Alcaligenes (Amann et al., 1995) and Burkholderia also have been identified (Quéméneur et al, 2008).

\subsection{Plant growth promoting attributes in As resistant, As (III) oxidizing bacterial strains:}

Recent studies have thrown some light on the PGP traits shown by the As oxidizing bacteria. The isolated bacterial strains of Acinetobacter $s p$., Klebsiella sp., Pseudomonas sp., Enterobacter sp. and Comamonas sp. from As- polluted tannery wastes under agricultural lands in Thailand (Das et al., 2014) possess both As tolerance and siderophore production (Ghosh et al., 2011). In the present investigation, one of our candidate isolate, Burkholderia sp has been previously reported to survive in lead and cadmium contaminated soils and also has ability to decrease cadmium translocation and enhance efficiencies of photosynthesis in rice (Jiang et al., 2008). The two candidate isolates BcAL1 and JN 73 has ability to solubilize a significant amount of phosphate and produce IAA. Most of bacteria under Pseudomonas sp., Acinetobacter sp. and Paenibacillus sp. were reported to be potential plant growth promoters (Das et al., 2014). Bacillus aryabhattai is an important As resistant plant growth promoter (Ghosh et al., 2018).

Similar observation were also obtained with As-resistant bacteria pertaining to Alpha proteobacteria, Beta proteobacteria, and Gamma proteobacteria manifesting potential PGP attributes (Cavalca et al., 2010; Ghosh et al., 2011). Staphylococus arlettae is another well known plant growth promoter, found in As laden soils, which increase plant protein, chlorophyll and carotenoides in Brassica (Srivastava et al., 2013). Pseudomonas sp. has been reported to possess high As(III) oxidizing capacity while at the same time found to solubilize significant amount of phosphate, indulge in siderophores, IAA like molecules and ACC Deaminase production (Das et al., 2014).

The present investigation has indisputably established the manifestation of PGP traits of As tolerant, As oxidizing bacterial isolates Burkholderia metallica, Burkholderia cepacia, Burkholderia cenocepacia, Burkholderia sp. in solubilizing phosphate, producing siderophores, root nodule, IAA-like molecules and ACC deaminase under As stress. Burkholderia capacia (BcAL-1) and Burkholderia metallica (JN 73) had emerged as best performing candidate isolates with regard to As resistance and PGP traits.

\section{Conclusion}

In pursuit of providing environmental safeguard to restore food safety and sustaining food security to burgeoning population and combat abiotic pollution, a low cost alternative to exorbitant pollution control strategies remained an absolute priority. The outcome of the present investigation envisioned the two candidate bacterial isolates Burkholderia cepacia (BcAL-1) and Burkholderia metallica (JN 73) may be useful, through fulfillment of mass production and field validation protocols, in As decontamination and plant growth promotion. This is quite a novel finding as the strains of Burkholderia as such have never been reported as arsenic resistant potential PGPR. The strains by virtue of being the most promising PGPR provide a great deal of novelty in the research area by merging high As resistant properties and exhibition of several important PGP traits. In terms of sustainable agricultural and novel crop production the strain can even solve the productivity conundrum in the contaminated study areas. This result can usher much confidence for use in As-contaminated field by employing further thorough field level investigations to support our laboratory results.

\section{Declarations}

\section{Acknowledgement:}

The authors are grateful to the ICAR-Niche area of Excellence-As Research Laboratory, Bidhan Chandra Krishi Viswavidyalaya (BCKV), Kalyani, Nadia as well as Department of Genetics \& Plant Breeding and Department of Agronomy, Bidhan Chandra Krishi Viswavidyalaya (BCKV), Mohanpur, Nadia, West Bengal, India for providing technical and all other necessary assistance during the study.

\section{Funding:}

This research did not receive any specific grant from funding agencies in the public, commercial, or not-for-profit sectors.

\section{Declaration of Competing Interest:}

The authors declare that they have no known competing financial interests or personal relationships that could have appeared to influence the work

Research involving Human Participants and/or Animals: 
This article does not contain any studies with human participants or animals performed by any of the authors.

\section{Informed consent:}

Informed consent was obtained from all individual participants included in the study.

\section{Author contributions:}

Aritri Laha: Methodology, Investigation, Data curation, Software and Writing- Original draft preparation; Somnath Bhattacharyya: Conceptualization, Methodology, Supervision; Sudip Sengupta: Data curation, Visualization, Software, Writing- Reviewing and Editing; Kallol

Bhattacharyya: Conceptualization, Methodology, Validation, Writing- Reviewing and Editing; Sanjoy GuhaRoy. Methodology, Supervision.

\section{References}

1. Abedin, M. J., Cotter-Howells, J., and Meharg, A. A. 2002. As uptake and accumulation in rice (Oryza sativa L.) irrigated with contaminated water. Plant and soil, 240(2), 311-319.

2. Amann, R.I., Ludwig, W. and Schleifer, K.H. 1995. Phylogenetic identification and in situ detection of individual microbial cells without cultivation. Microbiol. Mol. Biol. Rev., 59(1), 143-169.

3. Anderson, G.L., Williams, J. and Hille, R. 1992. The purification and characterization of As(III) oxidase from Alicaligenes faecalis, a molybdenum-containing hydroxylase. J. Biol. Chem. 267, 23674-23682.

4. Bachate, S.P., Cavalca, L. and Andreoni, V. 2009. As-resistant bacteria isolated from agricultural soils of Bangladesh and characterization of As(V)-reducing strains. Journal of applied microbiology, 107(1), 145-156.

5. Bachate, S.P., Khapare, R.M. and Kodam, K.M. 2012. Oxidation of As(III) by two ß-proteobacteria isolated from soil. Applied microbiology and biotechnology, 93(5), 2135-2145.

6. Bhattacharya, P., Samal A.C., Majumdar, J. and Santra, S.C. 2010. Uptake of As in rice plant varieties cultivated with As rich groundwater. Environment Asia. 3:34-37.

7. Bhattacharyya, K. and Sengupta, S. (2020). Arsenic management options in soil-plant-food chain. In: Proceedings of the National Webinar On Arsenic Mitigation: A Nexus Approach; (Prasad Bishun D., Mandal Jajati., Kumar Sunil., Sohane R K, Eds.), pp. 17-23

8. Bogdan K. and Schenk M.K. 2009. Evaluation of soil characteristics potentially affecting As concentration in paddy rice (Oryza sativa L.). Environmental Pollution 157:2617-2621

9. Botes, E., Van Heerden, E. and Litthauer, D. 2007. Hyper-resistance to As in bacteria isolated from an antimony mine in South Africa. South African Journal of Science, 103(7-8), 279-281.

10. Cavalca, L., Zanchi, R., Corsini, A., Colombo, M., Romagnoli, C., Canzi, E. and Andreoni, V. 2010. As-resistant bacteria associated with roots of the wild Cirsium arvense (L.) plant from an As polluted soil, and screening of potential plant growth-promoting characteristics. Systematic and applied microbiology, 33(3), 154-164.

11. Chakraborti, D., Rahman, M.M., Mukherjee, A., Alauddin, M., Hassan, M., Dutta, R.N., Pati, S., Mukherjee, S.C., Roy, S., Quamruzzman, Q. and Rahman, M. 2015. Groundwater As contamination in Bangladesh-21 Years of research. Journal of Trace Elements in Medicine and Biology, 31, 237-248.

12. Chowdhury, U. K., Rahaman, M. M., Mondal, B. K., Paul, K., Lodh, D., Biswas, B. K., Basu, G. K., Chanda, C. R., Saha, K. C., Mukherjee, S. C., Roy, S., Das, R., Kaies, I., Barua, A. K., Quamruzzaman, Q. and Chakraborti, D. 2001. Groundwater contamination and human suffering in West Bengal, India and Bangladesh, Environmental Science and Technology. 8: 393 - 415.

13. Das, S., Jean, J. S., Kar, S., and Liu, C. C. 2013. Changes in bacterial community structure and abundance in agricultural soils under varying levels of As contamination. Geomicrobiology Journal, 30(7), 635-644.

14. Das, S., Jean, J.S., Kar, S., Chou, M.L. and Chen, C.Y. 2014. Screening of plant growth-promoting traits in As-resistant bacteria isolated from agricultural soil and their potential implication for As bioremediation. Journal of hazardous materials, 272, $112-120$.

15. de-Bashan, L.E., Hernandez, J.P. and Bashan, Y. 2012. The potential contribution of plant growth-promoting bacteria to reduce environmental degradation- A comprehensive evaluation. Applied Soil Ecology, 61, 171-189.

16. Dereeper, A., Guignon, V., Blanc, G., Audic, S., Buffet, S., Chevenet, F., Dufayard, J.F., Guindon, S., Lefort, V., Lescot, M. and Claverie, J.M. 2008. Phylogeny. fr: robust phylogenetic analysis for the non-specialist. Nucleic acids research, 36(suppl_2), W465-W469.

17. Dey, U., Chatterjee, S., and Mondal, N. K. 2016. Isolation and characterization of As-resistant bacteria and possible application in bioremediation. Biotechnology reports, 10, 1-7. 
18. Ellis, P. J., Conrads, T., Hille, R., and Kuhn, P. 2001. Crystal structure of the $100 \mathrm{kDa}$ arsenite oxidase from Alcaligenes faecalis in two crystal forms at $1.64 \AA$ and $2.03 \AA$. Structure, 9(2), 125-132.

19. El-Meihy, R.M., Abou-Aly, H.E., Youssef, A.M., Tewfike, T.A., and El-Alkshar, E.A. 2019. Efficiency of heavy metals-tolerant plant growth promoting bacteria for alleviating heavy metals toxicity on sorghum. Environmental and Experimental Botany, 162, $295-301$.

20. Farooq MA, Islam F, Ali B, Najeeb U, Mao B, Gill RA, Yan G, Siddique KHM and Zhou W 2016. As toxicity in plants: Cellular and molecular mechanisms of its transport and metabolism. Environmental and Experimental Botany. 132:42-52.

21. Frankenberger, W. T. Jr. and Arshad, M. 2002. Volatilization of As. In: Frankenberger, W.T. Jr. (Ed.). Environmental chemistry of As. Marcel Dekker, New York, USA. 363 - 380.

22. Garnaga, G., Wyse, E., Azemard, S., Stankevičius, A., and De Mora, S. 2006. As in sediments from the southeastern Baltic Sea. Environmental Pollution, 144(3), 855-861.

23. Ghosh, P., Rathinasabapathi, B., and Ma, L. Q. 2011. As-resistant bacteria solubilized As in the growth media and increased growth of As hyperaccumulator Pteris vittata L. Bioresource technology, 102(19), 8756-8761.

24. Ghosh, P.K., Maiti, T.K., Pramanik, K., Ghosh, S.K., Mitra, S. and De, T.K. 2018. The role of As resistant Bacillus aryabhattai MCC3374 in promotion of rice seedlings growth and alleviation of As phytotoxicity. Chemosphere, 211, 407-419.

25. González, R. C., \&González-Chávez, M. C. A. 2006. Metal accumulation in wild plants surrounding mining wastes. Environmental Pollution, 144(1), 84-92.

26. Hartley,W., Edwards, R. and Lepp, N.W. 2004. As and heavy metal mobility in iron oxide-amended contaminated soils as evaluated by short-and long-term leaching tests. Environmental Pollution. 131: 495-504.

27. Holtz, J.D. 1993. Bergey's manual of determinative bacteriology. 9th ed. Baltimore: Williams and Wilkins.

28. Jackson, C.R., Harrison, K.G. and Dugas, S.L. 2005. Enumeration and characterization of culturable As(V) resistant bacteria in a large estuary. Systematic and applied microbiology, 28(8), 727-734.

29. Jiang, C.Y., Sheng, X.F., Qian, M. and Wang, Q.Y. 2008. Isolation and characterization of a heavy metal-resistant Burkholderia sp. from heavy metal-contaminated paddy field soil and its potential in promoting plant growth and heavy metal accumulation in metal-polluted soil. Chemosphere, 72(2), 157-164.

30. Johnston, S.E. and Barnard, W.M. 1979. Comparative Effectiveness of Fourteen Solutions for Extracting As from Four Western New York Soils 1. Soil Science Society of America Journal, 43(2), 304-308.

31. Kashyap, D. R., Botero, L. M., Lehr, C., Hassett, D. J., and McDermott, T. R. 2006. A Na+: H+ antiporter and a molybdate transporter are essential for arsenite oxidation in Agrobacterium tumefaciens. Journal of Bacteriology, 188(4), 1577-1584.

32. Kinegam, S., Yingprasertchai, T., Tanasupawat, S., Leepipatpiboon, N., Akaracharanya, A. and Kim, K.W. 2008. Isolation and characterization of As(III)-oxidizing bacteria from As-contaminated soils in Thailand. World Journal of Microbiology and Biotechnology, 24(12), 3091-3096.

33. Kumpiene, J., Ore, S., Renella, G., Mench, M., Lagerkvist, A. and Maurice, C. 2006. Assessment of zerovalent iron for stabilization of chromium,copper, and As in soil, Environmental Pollution. 144: 62-69

34. Lebrun, E., Brugna, M., Baymann, F., Muller, D., Lievremont, D., Lett, M.C. and Nitschke, W. 2003. As(III) oxidase, an ancient bioenergetic enzyme. Molecular biology and evolution, 20(5), 686-693.

35. Li, K. and Ramakrishna, W. 2011. Effect of multiple metal resistant bacteria from contaminated lake sediments on metal accumulation and plant growth. Journal of hazardous materials, 189(1-2), 531-539.

36. Liao, V.H.C., Chu, Y.J., Su, Y.C., Hsiao, S.Y., Wei, C.C., Liu, C.W., Liao, C.M., Shen, W.C. and Chang, F.J. 2011. As(III)-oxidizing and As(V)reducing bacteria associated with As-rich groundwater in Taiwan. Journal of contaminant hydrology, 123(1-2), 20-29.

37. Ma, Y., Prasad, M.N.V., Rajkumar, M. and Freitas, H. 2011. Plant growth promoting rhizobacteria and endophytes accelerate phytoremediation of metalliferous soils. Biotechnology advances, 29(2), 248-258.

38. Majumder, A., Bhattacharyya, K., Bhattacharyya, S. and Kole, S.C. 2013a. As-tolerant, As(III)-oxidising bacterial strains in the contaminated soils of West Bengal, India. Science of the total environment, 463, 1006-1014.

39. Majumder, A., Bhattacharyya, K., Kole, S. C., and Ghosh, S. 2013b. Efficacy of indigenous soil microbes in arsenic mitigation from contaminated alluvial soil of India. Environmental Science and Pollution Research, 20(8), 5645-5653.

40. Matera, V., Le Hecho, I., Laboudigue, A., Thomas, P., Tellier, S. and Astruc, M. 2003. A methodological approach for the identification of As bearing phases in polluted soils. Environmental Pollution. 126: 51-64.

41. Matschullat, J. 2000. As in the geosphere - a review. The Science of the Total Environment, 249: 297-312

Page 9/19 
42. Meharg, A. A., and Rahman, M. M. 2003. Arsenic contamination of Bangladesh paddy field soils: implications for rice contribution to arsenic consumption. Environmental science \& technology, 37(2), 229-234.

43. Muller, D., Lievremont, D., Simeonova, D. D., Hubert, J. C., and Lett, M. C. 2003. Arsenite oxidase aox genes from a metal-resistant $\beta$ proteobacterium. Journal of bacteriology, 185(1), 135-141.

44. Penrose, D.M. and Glick, B.R. 2003. Methods for isolating and characterizing ACC deaminase containing plant growth-promoting rhizobacteria. Physiologia plantarum, 118(1), 10-15.

45. Prasad, K.S., Subramanian, V. and Paul, J. 2009. Purification and characterization of As(III) oxidase from Arthrobacter sp. Biometals, 22(5), 711.

46. Quéméneur, M., Heinrich-Salmeron, A., Muller, D., Lièvremont, D., Jauzein, M., Bertin, P.N., Garrido, F. and Joulian, C. 2008. Diversity surveys and evolutionary relationships of aoxB genes in aerobic As(III)-oxidizing bacteria. Appl. Environ. Microbiol., 74(14), $4567-4573$.

47. Rajkumar, M., Sandhya, S., Prasad, M. N. V., and Freitas, H. 2012. Perspectives of plant-associated microbes in heavy metal phytoremediation. Biotechnology advances, 30(6), 1562-1574.

48. Reed, M.L.E. and Glick, B.R. 2013. Applications of plant growth-promoting bacteria for plant and soil systems. Applications of Microbial Engineering. Taylor and Francis, Enfield, CT, 181-229.

49. Rhine, E. D., Chadhain, S. N., Zylstra, G. J., and Young, L. Y. 2007. The arsenite oxidase genes (aroAB) in novel chemoautotrophic arsenite oxidizers. Biochemical and biophysical research communications, 354(3), 662-667.

50. Santini, J. M., and van den Hoven, R. N. 2004. Molybdenum-containing arsenite oxidase of the chemolithoautotrophic arsenite oxidizer NT-26. Journal of Bacteriology, 186(6), 1614-1619.

51. Sarkar, S., Basu, B., Kundu, C.K. and Patra, P.K. 2012. Deficit irrigation: An option to mitigate As load of rice grain in West Bengal, India. Agriculture, ecosystems \& environment, 146(1), 147-152.

52. Simeonova, D.D., Lièvremont, D., Lagarde, F., Muller, D.A., Groudeva, V.I. and Lett, M.C. 2004. Microplate screening assay for the detection of As(III)-oxidizing and As(V)-reducing bacteria. FEMS Microbiology Letters, 237(2), 249-253.

53. Sparks D.L., Page A.L., Helmke P.A., Leoppert R.H., Solthanpour P.N., Tabatabai M.A., Johnston C.T. and Sumner M.E. 2006. Methods of Soil Analysis. Part 3. Chemical Methods. Madison, Soil Science Society of America, 811-831.

54. Srivastava, S., Verma, P.C., Chaudhry, V., Singh, N., Abhilash, P.C., Kumar, K.V., Sharma, N. and Singh, N. 2013. Influence of inoculation of As-resistant Staphylococcus arlettae on growth and As uptake in Brassica juncea (L.) Czern. Var. R-46. Journal of hazardous materials, 262, 1039-1047.

55. Srivastava, S., Verma, P.C., Singh, A., Mishra, M., Singh, N., Sharma, N. and Singh, N. 2012. Isolation and characterization of Staphylococcus sp. strain NBRIEAG-8 from As contaminated site of West Bengal. Applied microbiology and biotechnology, 95(5), 12751291.

56. Sundararao, W.V.B. 1963. Phosphate dissolving organisms in the soil and rhizosphere. Indian. Jour. of Agr. Sci., 33, 272-278.

57. Xiong, X., Liu, X., Iris, K.M., Wang, L., Zhou, J., Sun, X., Rinklebe, J., Shaheen, S.M., Ok, Y.S., Lin, Z. and Tsang, D.C. 2019. Potentially toxic elements in solid waste streams: Fate and management approaches. Environmental Pollution, 253, 680-707.

58. Yoon, I.H., Chang, J.S., Lee, J.H. and Kim, K.W. 2009. As(III) oxidation by Alcaligenes sp. strain RS-19 isolated from As-contaminated mines in the Republic of Korea. Environmental geochemistry and health, 31(1), 109.

59. Zaidi, S., Usmani, S., Singh, B.R. and Musarrat, J. 2006. Significance of Bacillus subtilis strain SJ-101 as a bioinoculant for concurrent plant growth promotion and nickel accumulation in Brassica juncea. Chemosphere, 64(6), 991-997.

\section{Tables}

Table:-1. Arsenic removal by selected bacterial isolates 


\begin{tabular}{|c|c|c|c|c|c|c|c|c|}
\hline Isolates & $\begin{array}{l}\text { Arsenic } \\
(\mathrm{V}) \\
\text { residue } \\
\text { in } \\
\text { liquid } \\
\text { media } \\
(\mathrm{mM})\end{array}$ & $\begin{array}{l}\text { Arsenic }(\mathrm{V}) \\
\text { concentration } \\
\text { in cell pellet } \\
(\mathrm{mM})\end{array}$ & $\begin{array}{l}\text { Arsenic }(\mathrm{V}) \\
\text { concentration } \\
\text { in filter paper } \\
(\mathrm{mM})\end{array}$ & $\begin{array}{l}\text { Unaccounted } \\
\text { part(mM) }\end{array}$ & $\begin{array}{l}\text { Arsenic } \\
\text { (III) } \\
\text { residue } \\
\text { in } \\
\text { liquid } \\
\text { media } \\
(\mathrm{mM})\end{array}$ & $\begin{array}{l}\text { Arsenic } \\
\text { concentration(III) } \\
\text { in cell pellet } \\
(\mathbf{m M})\end{array}$ & $\begin{array}{l}\text { Arsenic } \\
\text { concentration } \\
\text { (III) in filter } \\
\text { paper } \\
(\mathrm{mM})\end{array}$ & $\begin{array}{l}\text { Unaccounted } \\
\text { part } \\
(\mathrm{mM})\end{array}$ \\
\hline BcAL-1 & $\begin{array}{l}1.25 \pm \\
1.14^{\mathrm{b}}\end{array}$ & $2.00 \pm 0.85^{a}$ & $1.63 \pm 0.43^{\mathrm{a}}$ & $\begin{array}{l}0.12 \pm \\
0.01^{\mathrm{abc}}\end{array}$ & $\begin{array}{l}2.00 \pm \\
1.28^{\mathrm{b}}\end{array}$ & $1.80 \pm 0.66^{\mathrm{a}}$ & $1.08 \pm 0.61^{\mathrm{ab}}$ & $0.12 \pm 0.03^{\mathrm{ab}}$ \\
\hline $\mathrm{JN}-73$ & $\begin{array}{l}1.32 \pm \\
1.06^{\mathrm{b}}\end{array}$ & $1.95 \pm 0.71^{\mathrm{a}}$ & $1.60 \pm 0.69^{\mathrm{ab}}$ & $0.13 \pm 0.02^{\mathrm{ab}}$ & $\begin{array}{l}2.00 \pm \\
0.97^{b}\end{array}$ & $1.80 \pm 1.04^{\mathrm{a}}$ & $1.07 \pm 0.80^{\mathrm{ab}}$ & $0.13 \pm 0.01^{\mathrm{ab}}$ \\
\hline LAR-2 & $\begin{array}{l}1.33 \pm \\
1.11^{\mathrm{b}}\end{array}$ & $1.93 \pm 0.55^{\mathrm{a}}$ & $1.59 \pm 0.66^{\mathrm{ab}}$ & $0.15 \pm 0.01^{\mathrm{a}}$ & $\begin{array}{l}2.10 \pm \\
1.15^{\mathrm{b}}\end{array}$ & $1.72 \pm 0.70^{\mathrm{a}}$ & $1.03 \pm 0.50^{\mathrm{ab}}$ & $0.15 \pm 0.01^{\mathrm{a}}$ \\
\hline AR-30 & $\begin{array}{l}1.50 \pm \\
1.28^{\mathrm{b}}\end{array}$ & $1.82 \pm 0.46^{\mathrm{a}}$ & $1.56 \pm 0.71^{\mathrm{ab}}$ & $\begin{array}{l}0.12 \pm \\
0.02^{\mathrm{abc}}\end{array}$ & $\begin{array}{l}2.24 \pm \\
1.37^{\mathrm{b}}\end{array}$ & $1.62 \pm 0.79^{a b}$ & $1.01 \pm 0.63^{c}$ & $0.13 \pm 0.02^{\mathrm{ab}}$ \\
\hline GAR-1 & $\begin{array}{l}2.25 \pm \\
1.74^{\mathrm{b}}\end{array}$ & $1.39 \pm 0.63^{\mathrm{a}}$ & $\begin{array}{l}1.25 \pm \\
1.09^{\mathrm{abc}}\end{array}$ & $0.11 \pm 0.02^{b c}$ & $\begin{array}{l}2.49 \pm \\
1.04^{\mathrm{b}}\end{array}$ & $1.45 \pm 1.04^{\mathrm{ab}}$ & $0.93 \pm 0.63^{a b}$ & $0.13 \pm 0.02^{\mathrm{a}}$ \\
\hline GAR-2 & $\begin{array}{l}3.48 \pm \\
1.06^{\mathrm{ab}}\end{array}$ & $1.00 \pm 0.75^{\mathrm{ab}}$ & $0.39 \pm 0.29^{\mathrm{cd}}$ & $0.13 \pm 0.02^{\mathrm{ab}}$ & $\begin{array}{l}4.14 \pm \\
1.13^{\mathrm{ab}}\end{array}$ & $0.50 \pm 0.39^{b c}$ & $0.24 \pm 0.18^{\mathrm{bc}}$ & $0.12 \pm 0.02^{\mathrm{ab}}$ \\
\hline LAR-7 & $\begin{array}{l}3.17 \pm \\
1.39^{\mathrm{ab}}\end{array}$ & $0.90 \pm 0.71^{\mathrm{ab}}$ & $\begin{array}{l}0.84 \pm \\
0.79^{\mathrm{abcd}}\end{array}$ & $0.09 \pm 0.01^{c}$ & $\begin{array}{l}4.09 \pm \\
1.30^{\mathrm{ab}}\end{array}$ & $0.52 \pm 0.34^{b c}$ & $0.25 \pm 0.18^{b c}$ & $0.14 \pm 0.02^{\mathrm{a}}$ \\
\hline GAR-11 & $\begin{array}{l}3.47 \pm \\
1.65^{\mathrm{ab}}\end{array}$ & $0.92 \pm 0.82^{\mathrm{ab}}$ & $\begin{array}{l}0.48 \pm \\
0.32^{\mathrm{bcd}}\end{array}$ & $0.13 \pm 0.02^{\mathrm{ab}}$ & $\begin{array}{l}3.99 \pm \\
1.25^{\mathrm{ab}}\end{array}$ & $0.52 \pm 0.37^{b c}$ & $\begin{array}{l}0.39 \pm \\
0.12^{\mathrm{abc}}\end{array}$ & $0.10 \pm 0.02^{b}$ \\
\hline LAR-20 & $\begin{array}{l}2.99 \pm \\
1.26^{\mathrm{ab}}\end{array}$ & $1.03 \pm 0.53^{\mathrm{ab}}$ & $\begin{array}{l}0.84 \pm \\
0.68^{\mathrm{abcd}}\end{array}$ & $0.14 \pm 0.02^{\mathrm{ab}}$ & $\begin{array}{l}3.25 \pm \\
1.10^{\mathrm{ab}}\end{array}$ & $0.99 \pm 0.43^{a b c}$ & $\begin{array}{l}0.66 \pm \\
0.26^{\mathrm{abc}}\end{array}$ & $0.10 \pm 0.02^{b}$ \\
\hline LAR-3 & $\begin{array}{l}3.00 \pm \\
1.40^{\mathrm{ab}}\end{array}$ & $1.00 \pm 0.57^{a b}$ & $\begin{array}{l}0.87 \pm \\
0.68^{\mathrm{abcd}}\end{array}$ & $0.13 \pm 0.02^{\mathrm{ab}}$ & $\begin{array}{l}3.32 \pm \\
1.27^{\mathrm{ab}}\end{array}$ & $0.99 \pm 0.39^{a b c}$ & $\begin{array}{l}0.59 \pm \\
0.20^{\mathrm{abc}}\end{array}$ & $0.10 \pm 0.01^{b}$ \\
\hline SAR-05 & $\begin{array}{l}4.87 \pm \\
1.54^{\mathrm{a}}\end{array}$ & ND & ND & $0.13 \pm 0.03^{a}$ & $\begin{array}{l}4.88 \pm \\
1.38^{\mathrm{a}}\end{array}$ & $0.00 \pm 0.00^{c}$ & ND & $0.12 \pm 0.02^{\mathrm{ab}}$ \\
\hline SEm ( $( \pm)$ & 0.70 & 0.34 & 0.33 & 0.01 & 0.63 & 0.34 & 0.25 & 0.01 \\
\hline $\begin{array}{l}C D \\
(P=0.05)\end{array}$ & 2.07 & 1.02 & 0.99 & 0.02 & 1.86 & 1.01 & 0.74 & 0.03 \\
\hline
\end{tabular}

Values with different alphabets are significantly different from each other according DMRT test $(P<0.05)$. Each value is a mean of three replicates. ND represents not detectable range.

Table:-2.MIC and As(III) oxidase enzyme activity of selected bacterial isolates 


\begin{tabular}{|c|c|c|c|c|}
\hline Bacterial Isolates & $\begin{array}{l}\text { MIC of } A s^{V} \\
(m M)\end{array}$ & $\begin{array}{l}\text { MIC of As } \\
(\mathrm{mM})\end{array}$ & Enzyme activity (nM & $\mathrm{min}^{-1} \mathrm{mg}^{-1}$ protein) \\
\hline BcAL-1 & $408 \pm 63.81^{\mathrm{a}}$ & $46.2 \pm 7.12^{\mathrm{a}}$ & $5.82 \pm 2.28^{a}$ & \\
\hline $\mathrm{JN}-73$ & $390 \pm 58.47^{a b}$ & $41.2 \pm 7.06^{\mathrm{ab}}$ & $5.30 \pm 2.67^{a}$ & \\
\hline LAR-2 & $300 \pm 64.57^{b c}$ & $31.3 \pm 7.36^{\mathrm{bc}}$ & $4.97 \pm 2.32^{\mathrm{a}}$ & \\
\hline AR-30 & $275 \pm 61.43^{c}$ & $28.1 \pm 7.76^{\mathrm{C}}$ & $4.60 \pm 2.30^{\mathrm{a}}$ & \\
\hline SAR-05 & ND & ND & $0.11 \pm 0.06^{b}$ & \\
\hline SEm ( \pm ) & 32.002 & 3.771 & 1.061 & \\
\hline$C D(P=0.05)$ & 98.608 & 11.620 & 3.181 & \\
\hline
\end{tabular}

Values with different alphabets are significantly different from each other according DMRT test $(P<0.05)$. Each value is a mean of three replicates. ND represents not detectable range.

Table:-3. Phenotypic and biochemical characterization of the isolates

\begin{tabular}{|llllllll|}
\hline Isolates & Gram stain & Cell shape & Cell length $(\mu)$ & Colony color & Oxidase & Catalase & Urease \\
\hline BcAL-1 & - & Rod & 2 & Milky White & + & + & + \\
\hline JN 73 & - & Rod & 2 & Milky White & + & + & + \\
\hline AR-30 & - & Rod & 2 & White & + & + & + \\
LAR-2 & - & Rod & 2 & White & + & + & + \\
\hline SAR-05 & - & Rod & 1.5 & Light pink & - & + & - \\
\hline
\end{tabular}

Table-4. Identification of the arsenic resistant plant growth promoting bacteria

\begin{tabular}{|llllll|}
\hline Isolates & $\begin{array}{l}\text { Sequence accession } \\
\text { number }\end{array}$ & $\begin{array}{l}\text { Identifying } \\
\text { bacteria }\end{array}$ & $\begin{array}{l}\text { Source of } \\
\text { isolation }\end{array}$ & $\begin{array}{l}\text { Arsenite } \\
\text { oxidase gene }\end{array}$ & $\begin{array}{l}\text { Arsenite oxidase gene } \\
\text { sequence number }\end{array}$ \\
\hline BcAL-1 & KJ461686 & $\begin{array}{l}\text { Burkholderia } \\
\text { cepacia }\end{array}$ & $\begin{array}{l}\text { Groundnut } \\
\text { rhizosphere }\end{array}$ & AOX-1 & MT995198 \\
\hline JN 73 & KJ507654 & $\begin{array}{l}\text { Burkholderia } \\
\text { metallica }\end{array}$ & $\begin{array}{l}\text { Groundnut } \\
\text { rhizosphere }\end{array}$ & ARS-2 & MT991554 \\
\hline AR-30 & KY992359 & $\begin{array}{l}\text { Burkholderia } \\
\text { cenocepacia }\end{array}$ & $\begin{array}{l}\text { Groundnut } \\
\text { rhizosphere }\end{array}$ & ARS-3 & MT991558 \\
\hline LAR-2 & MK634685 & Burkholderia sp & $\begin{array}{l}\text { Lentil } \\
\text { rhizosphere }\end{array}$ & ARS-4 & MT991559 \\
\hline $\begin{array}{l}\text { Control strain } \\
\text { (SAR-05) }\end{array}$ & MK713764 & Escherichia coli & Soil & - & - \\
\hline
\end{tabular}

Table-5. PGP Characteristics of the selected bacteria under varying levels of arsenate spiking 


\begin{tabular}{|c|c|c|c|c|c|c|}
\hline Isolates & $\begin{array}{l}\text { As spike } \\
(\mathrm{mg} / \mathrm{kg})\end{array}$ & $\begin{array}{l}\text { Phosphate } \\
\text { solubilization }\left(\mu \mathrm{gL}^{-1}\right)\end{array}$ & $\begin{array}{l}\text { IAA } \\
\text { Production } \\
(\mu \mathrm{M} \text { IAA ml- } \\
\left.{ }^{1}\right)\end{array}$ & $\begin{array}{l}\text { Acc deaminase activity } \\
\text { (nM a-ketobutyrate mg } \\
\text { protein }{ }^{-1} h^{-1} \text { ) }\end{array}$ & $\begin{array}{l}\text { Number of nodule } \\
\text { production }\end{array}$ & $\begin{array}{l}\text { Siderophore } \\
\text { production }\end{array}$ \\
\hline \multirow[t]{3}{*}{ BcAL-1 } & 0 & $570 \pm 1.00^{a}$ & $18.5 \pm 0.10^{\mathrm{a}}$ & $21.7 \pm 0.11^{b}$ & $112 \pm 1.73^{b c}$ & + \\
\hline & 15 & $568 \pm 1.00^{\mathrm{b}}$ & $18.6 \pm 0.20^{\mathrm{a}}$ & $22.0 \pm 0.10^{a}$ & $115 \pm 1.00^{\mathrm{a}}$ & + \\
\hline & 30 & $568 \pm 1.00^{\mathrm{b}}$ & $18.4 \pm 0.15^{a}$ & $22.0 \pm 0.10^{a}$ & $114 \pm 1.52^{\mathrm{ab}}$ & + \\
\hline \multirow[t]{3}{*}{ JN 73} & 0 & $563 \pm 1.00^{c}$ & $17.9 \pm 0.10^{\mathrm{bc}}$ & $19.0 \pm 0.10^{c}$ & $111 \pm 1.00^{c}$ & + \\
\hline & 15 & $563 \pm 1.00^{c}$ & $18.0 \pm 0.20^{b}$ & $19.0 \pm 0.10^{c}$ & $112 \pm 1.00^{\mathrm{bc}}$ & + \\
\hline & 30 & $561 \pm 1.00^{d}$ & $17.7 \pm 0.17^{\text {cde }}$ & $19.0 \pm 0.10^{c}$ & $110 \pm 1.00^{c}$ & + \\
\hline \multirow[t]{3}{*}{ AR-30 } & 0 & $553 \pm 1.00^{\mathrm{g}}$ & $17.4 \pm 0.11^{f}$ & $19.1 \pm 0.10^{c}$ & $112 \pm 1.00^{\mathrm{bc}}$ & + \\
\hline & 15 & $553 \pm 1.00^{\mathrm{g}}$ & $18.0 \pm 0.10^{b}$ & $19.1 \pm 0.05^{c}$ & $110 \pm 1.73^{c}$ & + \\
\hline & 30 & $553 \pm 1.00^{\mathrm{g}}$ & $17.6 \pm 0.15^{\text {def }}$ & $19.1 \pm 0.10^{c}$ & $111 \pm 1.52^{c}$ & - \\
\hline \multirow[t]{3}{*}{ LAR-2 } & 0 & $560 \pm 1.00^{\mathrm{de}}$ & $17.4 \pm 0.17^{f}$ & $17.9 \pm 0.10^{d}$ & $111 \pm 2.00^{c}$ & + \\
\hline & 15 & $558 \pm 0.577^{f}$ & $17.8 \pm 0.10^{\mathrm{bcd}}$ & $17.8 \pm 0.10^{d}$ & $114 \pm 1.00^{\mathrm{ab}}$ & + \\
\hline & 30 & $559 \pm 0.577^{\text {ef }}$ & $17.5 \pm 0.10^{\text {ef }}$ & $17.8 \pm 0.10^{d}$ & $114 \pm 1.00^{\mathrm{ab}}$ & - \\
\hline \multirow[t]{3}{*}{ SAR-05 } & 0 & $0.00 \pm 0.00^{h}$ & $0.00 \pm 0.00^{\mathrm{g}}$ & $0.00 \pm 0.00^{\mathrm{e}}$ & $1.00 \pm 0.00^{d}$ & - \\
\hline & 15 & $0.00 \pm 0.00^{h}$ & $0.00 \pm 0.00^{\mathrm{g}}$ & $0.00 \pm 0.00^{\mathrm{e}}$ & $1.00 \pm 0.00^{\mathrm{d}}$ & - \\
\hline & 30 & $0.00 \pm 0.00^{\mathrm{h}}$ & $0.00 \pm 0.00^{\mathrm{g}}$ & $0.00 \pm 0.00^{\mathrm{e}}$ & $1.00 \pm 0.00^{d}$ & - \\
\hline SEm ( $( \pm)$ & & 0.497 & 0.076 & 0.051 & 0.708 & - \\
\hline $\begin{array}{l}C D \\
(P=0.05)\end{array}$ & & 1.440 & 0.220 & 0.148 & 2.051 & - \\
\hline
\end{tabular}

Values with different alphabets are significantly different from each other according DMRT test $(P<0.05)$. Each value is a mean ofthree replicates.

Table-6. PGP Characteristics of selected bacteria under varying levels of arsenite spiking 


\begin{tabular}{|c|c|c|c|c|c|c|}
\hline Isolates & $\begin{array}{l}\text { As spike } \\
(\mathrm{Mm})\end{array}$ & $\begin{array}{l}\text { Phosphate } \\
\text { solubilization } \\
\left(\mu \mathrm{gL}^{-1}\right)\end{array}$ & $\begin{array}{l}\text { IAA } \\
\text { Production } \\
(\mu \mathrm{M} \text { IAA } \\
\left.\mathrm{ml}^{-1}\right)\end{array}$ & $\begin{array}{l}\text { Acc deaminase activity } \\
\text { (nM a-ketobutyrate mg } \\
\text { protein }{ }^{-1} h^{-1} \text { ) }\end{array}$ & $\begin{array}{l}\text { Number of nodule } \\
\text { production }\end{array}$ & $\begin{array}{l}\text { Siderophore } \\
\text { production }\end{array}$ \\
\hline \multirow{3}{*}{ BcAL-1 } & 0 & $570 \pm 106.78^{a}$ & $18.5 \pm 4.09^{a}$ & $21.7 \pm 6.40^{\mathrm{a}}$ & $112 \pm 3.26^{\mathrm{a}}$ & + \\
\hline & 15 & $268 \pm 107.30^{b}$ & $8.60 \pm 4.55^{b}$ & $12.00 \pm 2.00^{\mathrm{b}}$ & $104 \pm 3.08^{b}$ & + \\
\hline & 30 & $168 \pm 112.65^{\mathrm{bc}}$ & $8.4 \pm 4.10^{b}$ & $12.0 \pm 4.25^{b}$ & $100 \pm 3.06^{b}$ & + \\
\hline \multirow{3}{*}{ JN 73} & 0 & $563 \pm 110.12^{a}$ & $17.9 \pm 3.80^{\mathrm{a}}$ & $19.08 \pm 4.55^{\mathrm{a}}$ & $111 \pm 2.82^{\mathrm{a}}$ & + \\
\hline & 15 & $163 \pm 114.05^{b c}$ & $8.00 \pm 3.89^{b}$ & $12.06 \pm 1.60^{\mathrm{b}}$ & $102 \pm 3.53^{b}$ & + \\
\hline & 30 & $161 \pm 112.53^{\mathrm{bc}}$ & $7.70 \pm 4.67^{b}$ & $12.06 \pm 1.45^{\mathrm{b}}$ & $100 \pm 2.91^{b}$ & + \\
\hline \multirow[t]{3}{*}{ AR-30 } & 0 & $553 \pm 112.06^{a}$ & $17.5 \pm 4.06^{a}$ & $19.1 \pm 4.37^{a}$ & $112 \pm 3.34^{\mathrm{a}}$ & + \\
\hline & 15 & $248 \pm 113.56^{b}$ & $8.60 \pm 4.34^{b}$ & $12.00 \pm 1.35^{\mathrm{b}}$ & $104 \pm 3.27^{b}$ & - \\
\hline & 30 & $168 \pm 111.33^{b c}$ & $8.4 \pm 4.75^{b}$ & $12.0 \pm 4.25^{\mathrm{b}}$ & $100 \pm 3.55^{\mathrm{b}}$ & - \\
\hline \multirow[t]{3}{*}{ LAR-2 } & 0 & $560 \pm 117.01^{\mathrm{a}}$ & $17.4 \pm 3.75^{\mathrm{a}}$ & $17.9 \pm 4.56^{\mathrm{a}}$ & $111 \pm 2.76^{a}$ & + \\
\hline & 15 & $163 \pm 114.66^{\mathrm{bc}}$ & $8.00 \pm 4.40^{b}$ & $12.06 \pm 1.45^{b}$ & $102 \pm 2.60^{\mathrm{b}}$ & + \\
\hline & 30 & $161 \pm 118.50^{\mathrm{bc}}$ & $7.70 \pm 3.45^{b}$ & $12.06 \pm 1.50^{\mathrm{b}}$ & $100 \pm 3.15^{b}$ & - \\
\hline \multirow[t]{3}{*}{ SAR-05 } & 0 & $0.00 \pm 0.00^{\mathrm{e}}$ & $0.00 \pm 0.00^{c}$ & $0.00 \pm 0.00^{\mathrm{b}}$ & $1.00 \pm 0.36^{c}$ & - \\
\hline & 15 & $0.00 \pm 0.00^{\mathrm{e}}$ & $0.00 \pm 0.00^{c}$ & $0.00 \pm 0.00^{\mathrm{b}}$ & $0.00 \pm 0.00^{c}$ & - \\
\hline & 30 & $0.00 \pm 0.00^{e}$ & $0.00 \pm 0.00^{c}$ & $0.00 \pm 0.00^{b}$ & $0.00 \pm 0.00^{c}$ & - \\
\hline SEm ( \pm$)$ & & 60.180 & 2.216 & 1.906 & 1.652 & - \\
\hline $\begin{array}{l}C D \\
(P=0.05)\end{array}$ & & 174.335 & 6.419 & 5.521 & 4.786 & - \\
\hline
\end{tabular}

Values with different alphabets are significantly different from each other according DMRT test $(P<0.05)$. Each value is a mean of three replicates.

\section{Figures}



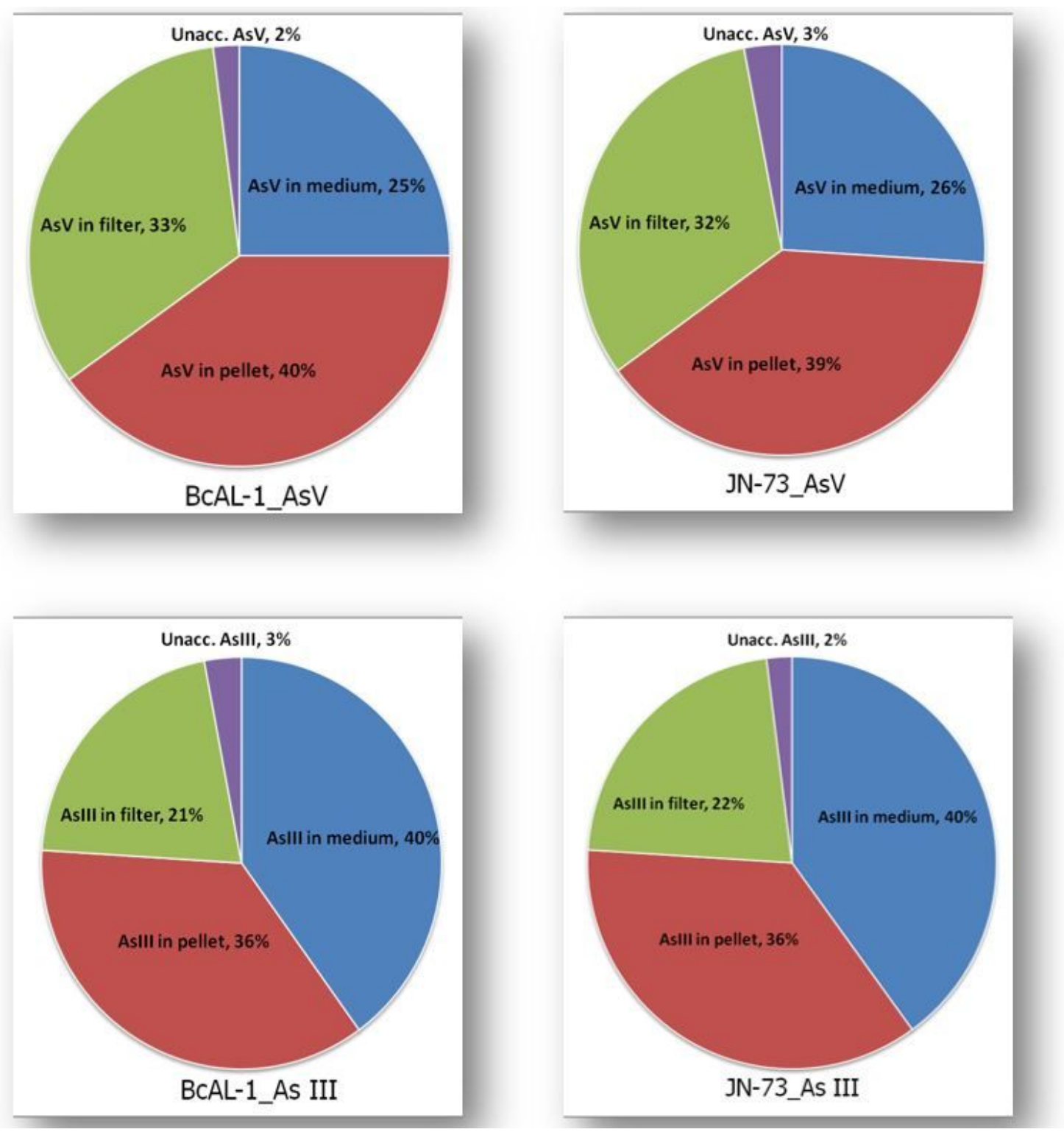

Figure 1

Arsenic balance-sheet of the experimental system 


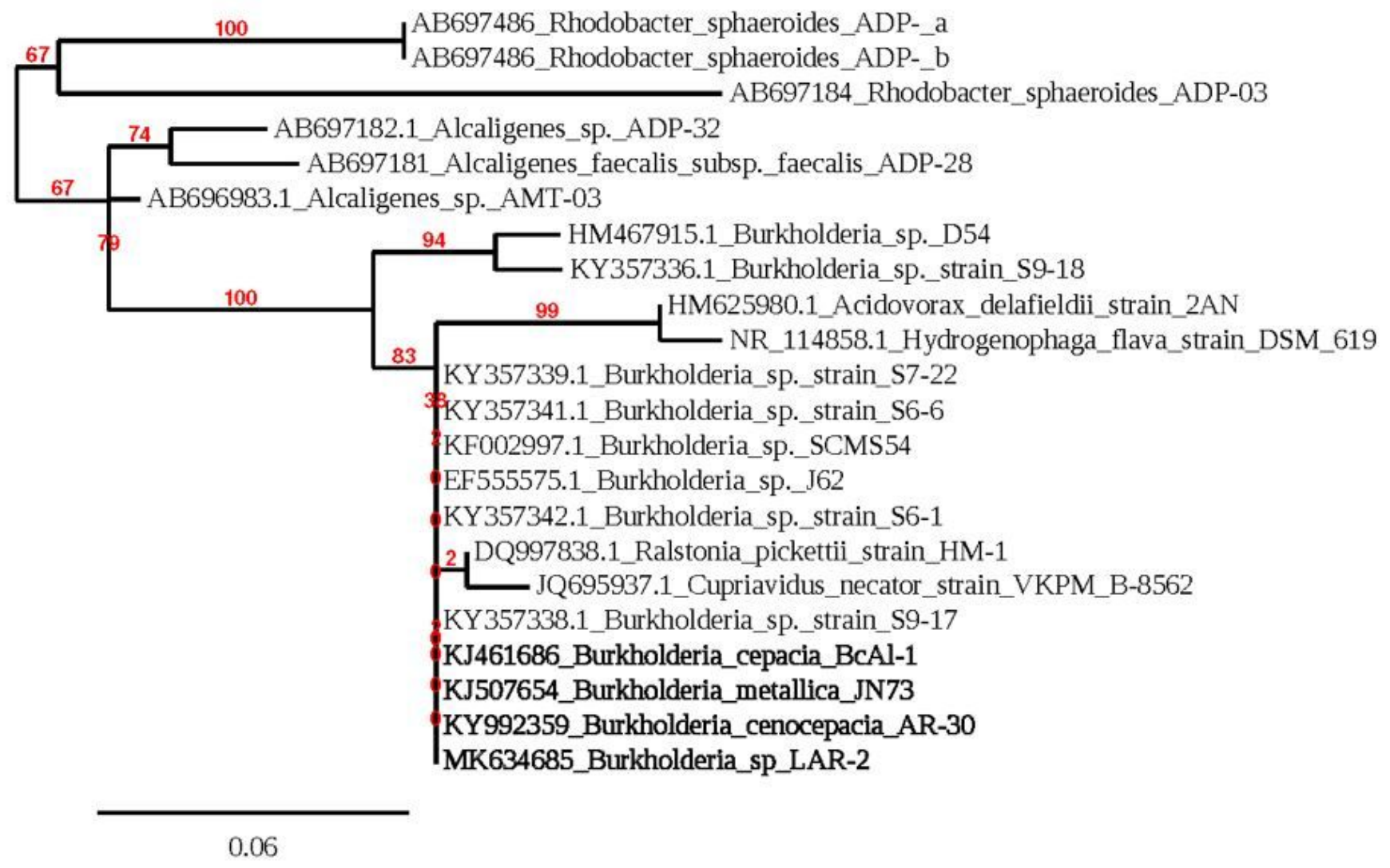

\section{Figure 2}

Phylogenetic tree based on partial 16S rRNA gene sequences arsenic and heavy metal tolerant bacterial isolates from arsenic contaminated soil and other arsenic oxidising bacterial isolates from the database. The database accession numbers are indicated before the name of bacteria. 


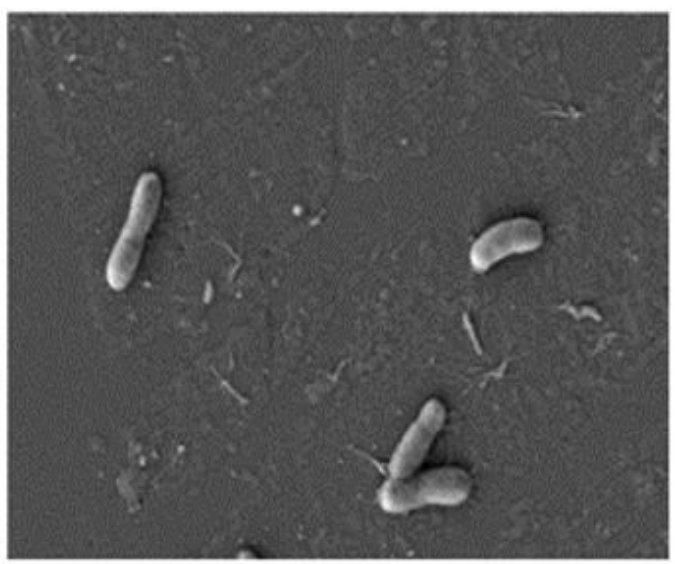

(a)

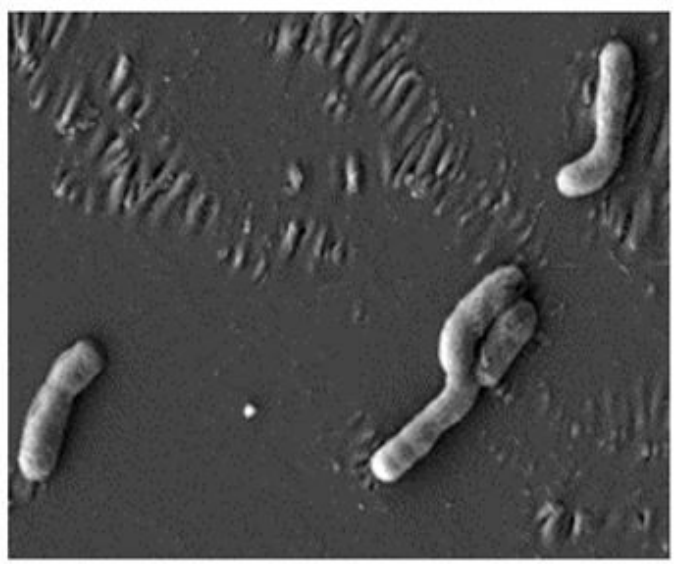

(c)

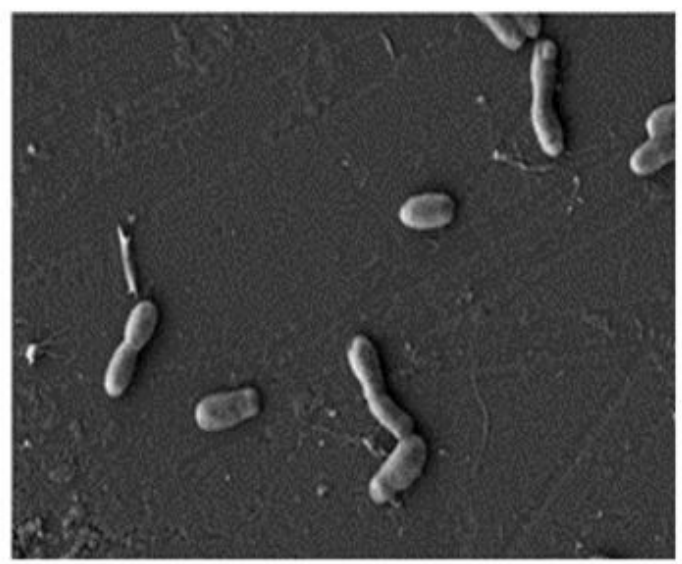

(b)

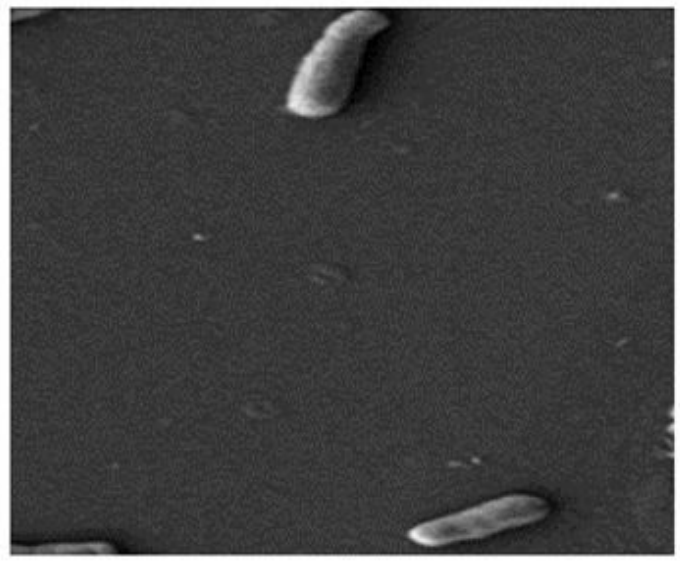

(d)

Figure 3

SEM imagery of selected bacterial isolates: (a) BcAL-1 (Burkholderia cepacia), (b) JN 73 (Burkholderia metallica), (c) AR-30 (Burkholderia cenocepacia) and (d) LAR-2 (Burkholderiasp) 


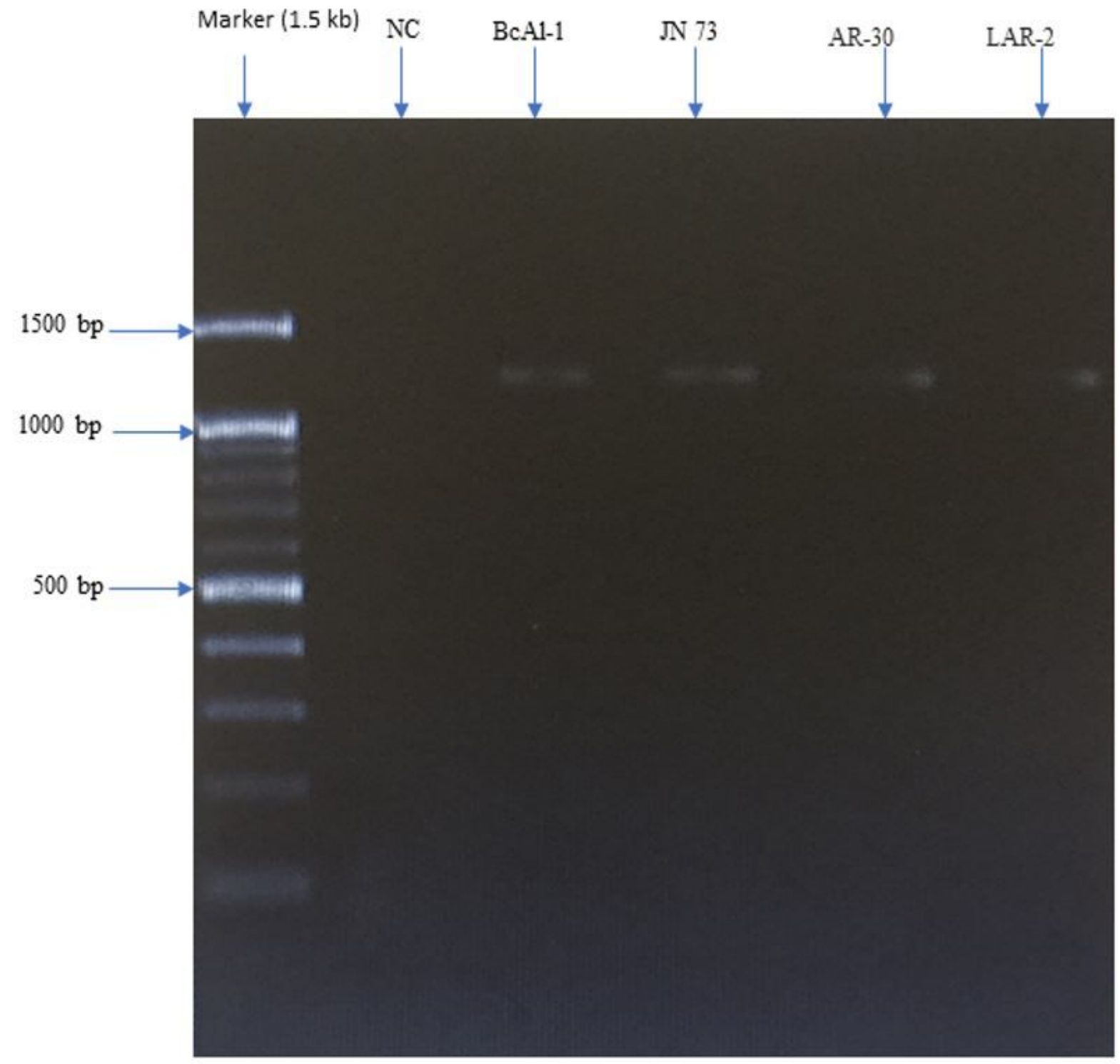

Figure 4

Agarose gel electrophoresis of PCR product obtained by amplifying aoxB from genomic DNA of four selected arsenic resistant bacterial isolates (lanes 3-6); (-) control (lane 2); marker 1001.5 kb DNA ladder (lane 1). 


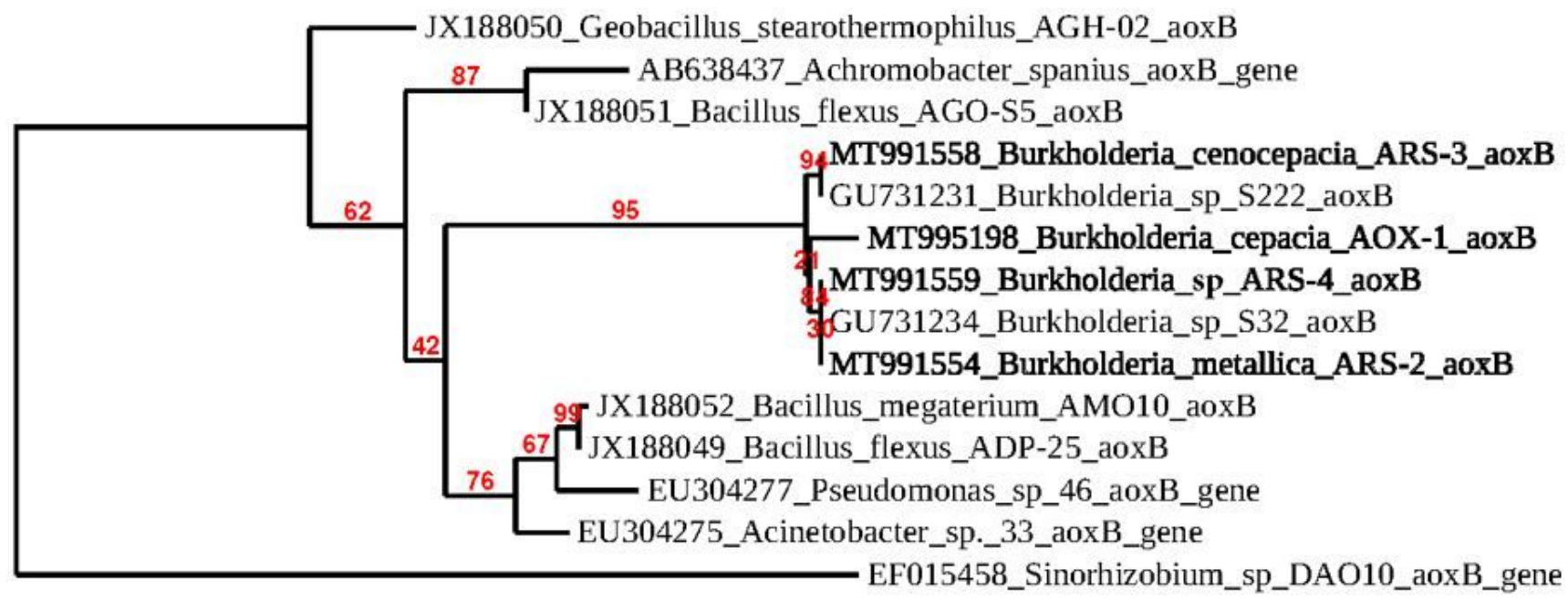

0.3

Figure 5

Phylogenetic tree based on partial aoxB gene sequences, including aoxB gene sequences of screened arsenic oxidising bacterial isolates from arsenic contaminated soil and aoxB of other arsenic oxidising bacterial isolates from the database. The database accession numbers are indicated before the name of bacteria. 